\title{
Anti-inflammatory and Cytotoxic Triterpenes from the Rot Roots of Panax notoginseng
}

\author{
Jia-Huan Shang ${ }^{1,2} \cdot$ Guo-Wei Xu ${ }^{1,2} \cdot$ Hong-Tao Zhu ${ }^{1,3} \cdot$ Dong Wang $^{1,3} \cdot$ Chong-Ren Yang ${ }^{1} \cdot$ Ying-Jun Zhang ${ }^{1,3}$ (i)
}

Received: 12 April 2019 / Accepted: 14 May 2019 / Published online: 23 May 2019

(c) The Author(s) 2019

\section{Abstract}

Four new protopanaxatriol-type triterpenes (1-2) and glucosides (3-4), were isolated from the rot roots of Panax notoginseng (Burk.) Chen, along with four known ones (5-8). Their structures were elucidated on the basis of extensive spectroscopic analysis (HRESIMS, NMR, UV, IR, and OR) and acidic hydrolysis. The possible transformation pathway of these compounds were also speculated from ginsenoside $\operatorname{Rg}_{1}$. Compound $\mathbf{1}$, with a unique $\alpha, \beta$-unsaturated ketene in its side chain, showed significant inhibitory effects against $\mathrm{NO}$ production on Murine macrophage cells $\left(\mathrm{IC}_{50}=4.12 \pm 0.20 \mu \mathrm{M}\right)$ and comparable cytotoxicities against five human cancer cell lines (myeloid leukemia HL-60, lung cancer A-549 cells, hepatocellular carcinoma SMMC7721, breast cancer MCF-7, and colon cancer SW480) to positive control, cisplatin (DDP).

\section{Graphical Abstract}
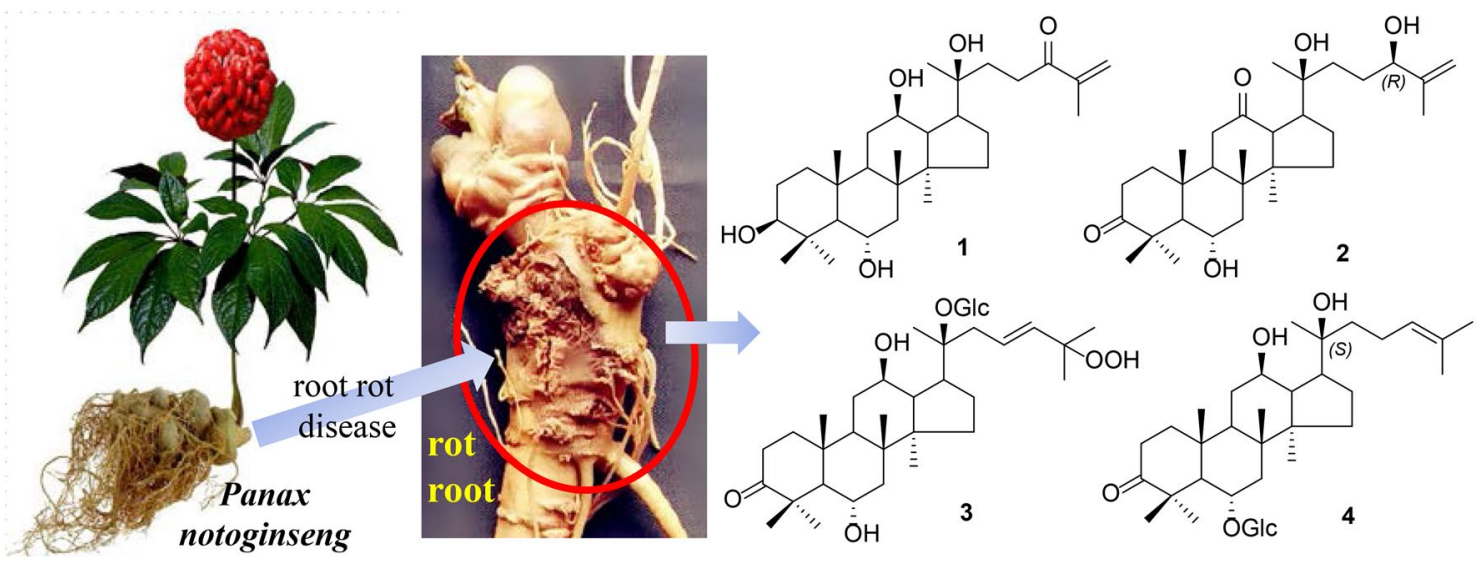

Keywords Panax notoginseng $\cdot$ Rot root · Triterpenes and saponins · Inhibition on NO production · Cytotoxicity

Electronic supplementary material The online version of this article (https://doi.org/10.1007/s13659-019-0211-4) contains supplementary material, which is available to authorized users.

Ying-Jun Zhang

zhangyj@mail.kib.ac.cn

1 State Key Laboratory of Phytochemistry and Plant Resources in West China, Kunming Institute of Botany, Chinese Academy of Sciences, Kunming 650201, People's Republic of China
2 University of Chinese Academy of Sciences, Beijing 100049, People's Republic of China

3 Yunnan Key Laboratory of Natural Medicinal Chemistry, Kunming Institute of Botany, Chinese Academy of Sciences, Kunming 650201, People's Republic of China 


\section{Introduction}

Panax notoginseng (Burk.) Chen (Araliaceae), a well-known member called Sanqi or Tianqi in Ginseng family for the treatment of cardiovascular diseases, has been domesticated and cultivated for more than 400 years in the southwest of China [1]. It is now used as one of the major raw materials for many traditional Chinese medicinal preparations, such as Pien Tze Huang, Yunnan Baiyao, Sanqi oral liquid, etc. [2]. Due to the increasing demands from medicinal industry and herbal market, the plantation of Sanqi has been enlarged sharply in recent decades. However, it is susceptible to various diseases during the plantation, because of the sensitive property to environmental factors. Among which, root rot caused mainly by microbial infections is the main destructive disease [3-5].

So far, more than 200 chemical compounds including triterpenoid saponins, flavonoids, amino acids, and so on, have been reported from the roots, stems, leaves, flower heads, fruits, and fruit pedicels, and ginsenosides are found to be the dominant active principles [6]. Previous HPLC-HRMS study revealed that the oxidation levels of constituents in roots of $P$. notoginseng are significantly increased after being infected by root rot diseases [7]. In order to clarify the chemical composition and explore the possible transformation mechanism in the rot roots of $P$. notoginseng, the minor chemical constituents of the rot root were studied in detail firstly. This led to the identification of four new (1-4) and four known (5-8) triterpenes and saponins (Fig. 1), and their possible transformation pathway were speculated in this paper. All the isolates were evaluated for their anti-inflammatory activity (inhibition NO production) on Murine macrophage cells and cytotoxicities against five human cancer cell lines.

\section{Results and discussion}

The air-dried rot roots of $P$. notoginseng were crushed into small grains and extracted with $\mathrm{MeOH}$. Further repeated column chromatography (CC) over macroporous resin D101, silica gel and RP-18, followed by semi-preparative HPLC, yielded eight dammarane type triterpenes. Four of them (1-4) including two saponins (3-4) are new compounds.

Compound 1 was obtained as white amorphous powder. Its molecular formula $\mathrm{C}_{30} \mathrm{H}_{50} \mathrm{O}_{5}$ was determined by the positive-mode HRESIMS $\left(\mathrm{m} / z\right.$ 513.3551 $\left.[\mathrm{M}+\mathrm{Na}]^{+}\right)$, corresponding to six degrees of unsaturation. The IR spectrum indicated the presence of hydroxy groups $\left(3391 \mathrm{~cm}^{-1}\right)$, keto $\left(1738 \mathrm{~cm}^{-1}\right)$, double bond $\left(1674 \mathrm{~cm}^{-1}\right)$ and methyls $\left(2954 \mathrm{~cm}^{-1}\right)$. The UV spectrum presented a weak absorption at $254 \mathrm{~nm}$ (K-band) indicating the existence of a conjugated $\alpha, \beta$-unsaturated ketene in this structure. The ${ }^{13} \mathrm{C}$ NMR spectrum (Table 1) showed the presence of 30 carbon resonances, assignable to seven methyls, nine methylenes with a vinyl $\left(\delta_{\mathrm{C}} 124.9\right)$, seven methines with three oxygenbearing ones $\left(\delta_{\mathrm{C}} 68.1,71.6\right.$ and 78.9), and seven quaternary carbons, including one oxygenated carbon $\left(\delta_{\mathrm{C}} 72.9\right)$, one olefinic carbon $\left(\delta_{\mathrm{C}} 145.2\right)$ and one ketone $\left(\delta_{\mathrm{C}} 203.2\right)$. The ${ }^{1} \mathrm{H}$ NMR spectrum (Table 2) displayed seven singlet methyls at $\delta_{\mathrm{H}} 2.02,1.89,1.47,1.38,1.10,1.01$ and 0.97 (each $3 \mathrm{H}, \mathrm{s}$ ), two olefinic protons at $\delta_{\mathrm{H}} 6.06$ and 5.66 (each $1 \mathrm{H}, \mathrm{s})$, three oxymethines at $\delta_{\mathrm{H}} 4.43(\mathrm{t}, J=8.5 \mathrm{~Hz}), 3.54$ $(\mathrm{d}, J=10.8 \mathrm{~Hz})$, and $3.95(\mathrm{t}, J=10.8 \mathrm{~Hz})$, and four active hydrogen protons at $\delta_{\mathrm{H}} 7.39,7.02,5.79,5.32$ (each $1 \mathrm{H}, \mathrm{s}$ ). The two of six unsaturated degrees were from the carbonyl and double bond. Above analysis displayed 1 to be a tetracyclic triterpene. The NMR data of $\mathbf{1}$ were similar to those of 20(S)-protopanaxatriol (PPT) [8], except for an additional ketone $\left(\delta_{\mathrm{C}} 203.2\right)$, the shielding of C-25 ( $\delta_{\mathrm{C}} 145.2$ vs $\delta_{\mathrm{C}}$ 150.4 in PPT), and the appearance of a terminal vinyl at $\mathrm{C}-25\left(\delta_{\mathrm{C}} 124.9\right)$. This indicated 1 to be a PPT-type triterpene with an $\alpha, \beta$-unsaturated ketone $(\mathrm{C}-24)$ on the side chain. The ${ }^{1} \mathrm{H}-{ }^{1} \mathrm{H}$ COSY correlations from $\mathrm{H}_{2}-22\left(\delta_{\mathrm{H}} 3.31,3.02\right)$ to $\mathrm{H}_{2}-23\left(\delta_{\mathrm{H}} 2.39,2.05\right)$ combined with the HMBC spectrum of $\mathrm{H}-22 / \mathrm{H}-23 / \mathrm{H}_{2}-26\left(\delta_{\mathrm{H}} 6.06,5.66\right) / \mathrm{H}-27\left(\delta_{\mathrm{H}} 1.89\right)$ to C-24 $\left(\delta_{\mathrm{C}} 203.2\right), \mathrm{H}-26 / \mathrm{H}-27$ to $\mathrm{C}-25\left(\delta_{\mathrm{C}} 145.2\right), \mathrm{H}-17\left(\delta_{\mathrm{H}}\right.$ $2.37) / \mathrm{H}-21\left(\delta_{\mathrm{H}} 1.38\right) / \mathrm{H}-22 / \mathrm{H}-23$ to $\mathrm{C}-20\left(\delta_{\mathrm{C}} 72.9\right)$, and of an active hydrogen signals $\left(20-\mathrm{OH}, \delta_{\mathrm{H}} 7.02\right)$ to $\mathrm{C}-20 / \mathrm{C}-21\left(\delta_{\mathrm{C}}\right.$ 27.5) (Fig. 2), respectively, further verified the structure of $\mathbf{1}$.

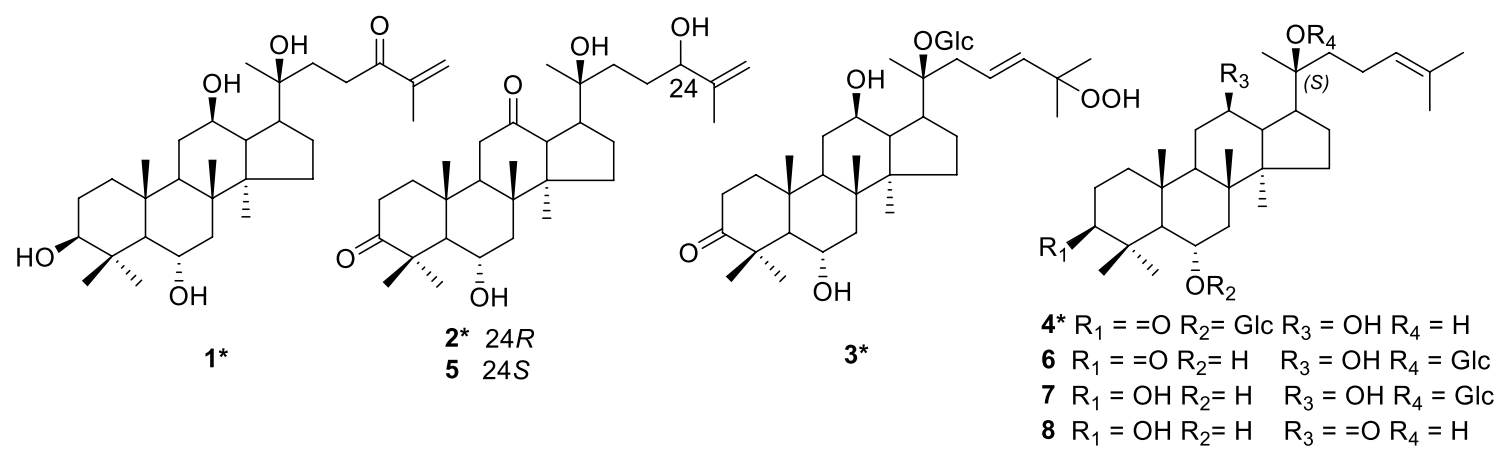

Fig. 1 Compounds 1-8 isolated from the rot roots of P. notoginseng 
Table $1{ }^{13} \mathrm{C}(150 \mathrm{MHz}) \mathrm{NMR}$ data of 1-4 in pyridine- $d_{5}$ ( $\delta$ in ppm)

\begin{tabular}{|c|c|c|c|c|c|c|c|c|c|}
\hline No. & 1 & 2 & 3 & 4 & No. & 1 & 2 & 3 & 4 \\
\hline 1 & 39.8 & 39.7 & 40.3 & 40.5 & 19 & 17.9 & 17.9 & 17.5 & 18.7 \\
\hline 2 & 28.6 & 33.5 & 33.8 & 33.7 & 20 & 72.9 & 73.7 & 83.5 & 73.5 \\
\hline 3 & 78.9 & 218.7 & 219.1 & 219.0 & 21 & 27.5 & 27.4 & 23.7 & 27.5 \\
\hline 4 & 40.8 & 48.1 & 48.1 & 48.6 & 22 & 33.2 & 38.9 & 40.3 & 36.3 \\
\hline 5 & 62.2 & 59.1 & 59.5 & 58.4 & 23 & 30.5 & 31.4 & 127.0 & 23.5 \\
\hline 6 & 68.1 & 67.2 & 67.3 & 79.8 & 24 & 203.2 & 76.5 & 138.6 & 126.8 \\
\hline 7 & 48.0 & 45.1 & 45.8 & 43.8 & 25 & 145.2 & 150.4 & 81.8 & 131.3 \\
\hline 8 & 41.6 & 41.6 & 41.0 & 40.7 & 26 & 124.9 & 110.8 & 25.6 & 26.3 \\
\hline 9 & 50.6 & 53.5 & 49.0 & 48.8 & 27 & 18.3 & 18.4 & 25.9 & 18.2 \\
\hline 10 & 39.8 & 38.6 & 38.6 & 38.9 & 28 & 32.4 & 32.4 & 32.6 & 32.3 \\
\hline 11 & 32.6 & 40.6 & 32.2 & 33.3 & 29 & 17.0 & 20.3 & 20.5 & 20.2 \\
\hline 12 & 71.6 & 211.4 & 70.7 & 71.2 & 30 & 17.5 & 17.4 & 16.7 & 17.1 \\
\hline 13 & 48.6 & 56.5 & 49.8 & 49.3 & $1^{\prime}$ & & & 98.8 & 105.8 \\
\hline 14 & 52.1 & 56.3 & 51.9 & 52.2 & $2^{\prime}$ & & & 75.8 & 75.9 \\
\hline 15 & 31.8 & 32.6 & 31.1 & 31.7 & $3^{\prime}$ & & & 79.4 & 80.1 \\
\hline 16 & 27.3 & 24.9 & 26.8 & 27.3 & $4^{\prime}$ & & & 72.1 & 72.4 \\
\hline 17 & 55.2 & 44.4 & 52.5 & 55.1 & $5^{\prime}$ & & & 78.8 & 78.6 \\
\hline 18 & 18.0 & 16.3 & 18.2 & 16.5 & $6^{\prime}$ & & & 63.5 & 63.6 \\
\hline
\end{tabular}

The $20 S$ configuration in $\mathbf{1}$ was constructed by comparison of the chemical shifts of C-21 $\left(\delta_{\mathrm{C}} 27.5\right)$ and C-17 $\left(\delta_{\mathrm{C}} 55.2\right)$ with those of $20 R$ configuration [C-21 $\left(\delta_{\mathrm{C}} 22.8\right)$ and C-17 $\left.\left(\delta_{\mathrm{C}} 50.7\right)\right][9,10]$. Therefore, compound 1 was identified as $3 \beta, 6 \alpha, 12 \beta, 20(S)$-tetrahydroxydammar-24-one-25-ene.

Compound 2 presented a molecular formula $\mathrm{C}_{30} \mathrm{H}_{48} \mathrm{O}_{5}$ with seven degrees of unsaturation as deduced from HRESIMS experiment $\left(\mathrm{m} / z 511.3399[\mathrm{M}+\mathrm{Na}]^{+}\right)$. The ${ }^{13} \mathrm{C}$ NMR spectrum of 2 showed an olefinic $\left(\delta_{\mathrm{C}} 150.4\right.$, $110.8)$, two carbonyl groups $\left(\delta_{\mathrm{C}} 218.7,211.4\right)$, while the ${ }^{1} \mathrm{H}$ NMR indicated the existence of three active hydrogens at $\delta_{\mathrm{H}} 5.48, \delta_{\mathrm{H}} 5.87, \delta_{\mathrm{H}} 6.46$, two oxymethines at $\delta_{\mathrm{H}} 4.42$ $(\mathrm{t}, J=6.0 \mathrm{~Hz}), \delta_{\mathrm{H}} 4.27$, and two vinyl protons at $\delta_{\mathrm{H}} 5.25$ and $\delta_{\mathrm{H}}$ 4.97. An oxygen-bearing methine at $\delta_{\mathrm{H}} 4.42(\mathrm{H}-24)$ was correlated with $\delta_{\mathrm{C}} 31.4(\mathrm{C}-23) / \delta_{\mathrm{C}} 150.4(\mathrm{C}-25) / \delta_{\mathrm{C}} 18.4$ (C-27) in HMBC spectrum (Fig. 2), suggesting a terminal enol moiety in the side chain. The ${ }^{1} \mathrm{H}$ and ${ }^{13} \mathrm{C}$ NMR data of 2 were strikingly similar to those of $6 \alpha, 20(S), 24(S)$ trihydroxydammar-3,12-dione-25-ene (5) [11], which was obtained from semi-preparative HPLC together with $\mathbf{2}$, showing discernible retention times (28.903 $\mathrm{min}$ for $\mathbf{5}$ and $31.587 \mathrm{~min}$ for 2) (SI). Dammanrane-type triterpenes, deriving from the all-chair formed epoxysqualene, requires $\beta$-configuration of $\mathrm{H}-13, \mathrm{CH}_{3}-18, \mathrm{CH}_{3}-19$ and the side chain at C-17 [12]. ROESY correlations from $\mathrm{H}-17$ to $\mathrm{H}-13$ and $\mathrm{CH}_{3}-21$ further facilitated assignment of the $20 S$-configuration for both $\mathbf{2}$ and $\mathbf{5}$ [13]. The very small difference for the upfield shift of H-26a $\left(\delta_{\mathrm{H}} 5.25\right.$ vs $\delta_{\mathrm{H}} 5.28$ in 5), C-27 ( $\delta_{\mathrm{C}} 18.4$ vs $\delta_{\mathrm{C}} 18.8$ in 5) and downfield shift of $\mathrm{H}-27\left(\delta_{\mathrm{H}} 1.92\right.$ vs $\delta_{\mathrm{H}} 1.90$ in 5), C24-C26 ( $\delta_{\mathrm{C}} 76.4,150.4$, 110.8 vs $\delta_{\mathrm{C}} 76.3,150.3,110.6$ in 5) suggested 2 to be a stereoisomer of $\mathbf{5}$ at C-24. Compound $\mathbf{2}$ showed a positive optical rotation $\left([\alpha]_{\mathrm{D}}^{25}+94.95\right)$, which is opposite to that of $5\left([\alpha]_{\mathrm{D}}^{25}-51.5\right)[11]$, revealed the $24 R$-configuration in 2. Accordingly, compound $\mathbf{2}$ was determined to be $6 \alpha, 20(S), 24(R)$-trihydroxydammar-3,12-dione-25-ene.

Compound 3 was found to have a molecular formula of $\mathrm{C}_{36} \mathrm{H}_{60} \mathrm{O}_{11}$ on basis of the positive-mode HRESIMS experiment $\left(\mathrm{m} / \mathrm{z} 691.4024[\mathrm{M}+\mathrm{Na}]^{+}\right)$. The ${ }^{13} \mathrm{C}$ NMR and DEPT spectra showed six more carbon resonances than those of $\mathbf{1}$, suggesting the existence of a hexosyl unit $\left(\delta_{\mathrm{C}} 98.8 \mathrm{~d}, 79.4\right.$ d, $78.8 \mathrm{~d}, 75.8 \mathrm{~d}, 72.1 \mathrm{~d}, 63.5 \mathrm{t}$ ). So far, all hexosyl units in ginsenosides isolated from Panax species is only glucosyl (Glc) [14]. Further acidic hydrolysis of $\mathbf{3}$ followed by GC analysis of the corresponding trimethylsilylated L-cysteine adduct characterized a glucopyranosyl moiety in compound 3 . The ${ }^{1} \mathrm{H}-\mathrm{NMR}$ spectrum of $\mathbf{3}$ showed an anomeric proton signal of the $\beta$-D-glucopyranosyl moiety at $\delta_{\mathrm{H}} 5.26$ $(\mathrm{d}, J=7.7 \mathrm{~Hz})$, an active hydrogen at $\delta_{\mathrm{H}} 14.37(\mathrm{~s})$ and two olefinic protons in a disubstituted $E$-double bond at $\delta_{\mathrm{H}} 6.08$ $(\mathrm{d}, J=15.7 \mathrm{~Hz})$ and $\delta_{\mathrm{H}} 6.21(\mathrm{~m})$. The ${ }^{13} \mathrm{C}$ and ${ }^{1} \mathrm{H}$ NMR data of 3 were similar to those of a ginsenoside- $\mathrm{Rh}_{6}$ [15], except for the signals of $\mathrm{C} 1-\mathrm{C} 5$ at ring A. The very down field chemical shift at $\delta_{\mathrm{C}} 219.1$ suggested that 3 should be 3-oxidized ginsenoside- $\mathrm{Rh}_{6}$ as the hydroxy group at C-3 $\left(\delta_{\mathrm{C}} 78.6\right)$ in ginsenoside- $\mathrm{Rh}_{6}$ was transferred to a ketone group. This 
Table $2{ }^{1} \mathrm{H}(600 \mathrm{MHz}) \mathrm{NMR}$ data of $\mathbf{1}-\mathbf{4}$ in pyridine- $d_{5}(\delta$ in ppm, $J$ in $\mathrm{Hz}$ )

\begin{tabular}{|c|c|c|c|c|}
\hline No. & 1 & 2 & 3 & 4 \\
\hline 1 & $1.68 \mathrm{~m}, 1.03 \mathrm{~m}$ & $1.55 \mathrm{~m}$ & $1.80 \mathrm{~m}, 1.59 \mathrm{~m}$ & $1.75 \mathrm{~m}, 1.56 \mathrm{~m}$ \\
\hline 2 & $1.93 \mathrm{~m}, 1.86 \mathrm{~m}$ & $2.81 \mathrm{~m}, 2.30 \mathrm{~m}$ & $2.80 \mathrm{~m}, 2.32 \mathrm{~m}$ & $2.83 \mathrm{~m}, 2.31 \mathrm{~m}$ \\
\hline 3 & $3.54 \mathrm{~d}(10.8)$ & & & \\
\hline $\mathrm{OH}-3$ & $5.79 \mathrm{~s}$ & & & \\
\hline 5 & $1.23 \mathrm{~d}(10.4)$ & $1.95 \mathrm{~d}(10.8)$ & $1.93 \mathrm{~m}$ & $2.15 \mathrm{~d}(10.6)$ \\
\hline 6 & $4.43 \mathrm{t}(8.5)$ & $4.27 \mathrm{~m}$ & $4.23 \mathrm{~m}$ & $4.29 \operatorname{td}(10.7,3.8)$ \\
\hline OH-6 & $5.32 \mathrm{~s}$ & $5.85 \mathrm{~s}$ & $5.71 \mathrm{~s}$ & \\
\hline \multirow[t]{2}{*}{7} & $1.98 \mathrm{~m}$ & $1.93 \mathrm{~m}$ & $1.88 \mathrm{~m}$ & $2.64 \mathrm{dd}(12.9,3.8)$ \\
\hline & $1.91 \mathrm{~m}$ & $1.89 \mathrm{~m}$ & & $1.93 \mathrm{~d}(12.1)$ \\
\hline 9 & $1.60 \mathrm{~m}$ & $1.99 \mathrm{dd}(13.0,4.3)$ & $1.66 \mathrm{~m}$ & $2.06 \mathrm{~m}$ \\
\hline 11 & $2.16 \mathrm{~m}, 1.25 \mathrm{~m}$ & $2.31 \mathrm{~m}$ & $2.03 \mathrm{~m}, 1.53 \mathrm{~m}$ & $2.04 \mathrm{~m}, 2.15 \mathrm{~m}$ \\
\hline 12 & $3.95 \mathrm{t}(10.8)$ & & $4.03 \mathrm{~m}$ & $3.90 \mathrm{~m}$ \\
\hline $\mathrm{OH}-12$ & $7.39 \mathrm{~s}$ & & $7.40 \mathrm{~s}$ & $7.29 \mathrm{~s}$ \\
\hline 13 & $2.09 \mathrm{t}(10.9)$ & $3.43 \mathrm{~d}(9.6)$ & $2.01 \mathrm{~m}$ & $1.66 \mathrm{~m}$ \\
\hline 15 & $1.58 \mathrm{~m}$ & $1.88 \mathrm{~m}, 1.19 \mathrm{~m}$ & $1.51 \mathrm{~m}, 1.01 \mathrm{~m}$ & $1.69 \mathrm{~m}, 1.28 \mathrm{~m}$ \\
\hline 16 & $1.88 \mathrm{~m}, 1.42 \mathrm{~m}$ & $2.16 \mathrm{~m}, 1.88 \mathrm{~m}$ & $1.80 \mathrm{~m}, 1.44 \mathrm{~m}$ & $1.84 \mathrm{~m}, 1.38 \mathrm{~m}$ \\
\hline 17 & $2.37 \mathrm{~m}$ & $2.78 \mathrm{~m}$ & $2.49 \mathrm{~m}$ & $2.34 \mathrm{~m}$ \\
\hline 18 & $1.01 \mathrm{~s}$ & $1.24 \mathrm{~s}$ & $0.88 \mathrm{~s}$ & $1.13 \mathrm{~s}$ \\
\hline 19 & $1.10 \mathrm{~s}$ & $0.82 \mathrm{~s}$ & $0.74 \mathrm{~s}$ & $0.88 \mathrm{~s}$ \\
\hline $\mathrm{OH}-20$ & 7.02 & 5.48 & & 7.03 \\
\hline 21 & $1.38 \mathrm{~s}$ & $1.47 \mathrm{~s}$ & $1.62 \mathrm{~s}$ & $1.43 \mathrm{~s}$ \\
\hline \multirow[t]{2}{*}{22} & $3.31 \mathrm{~m}$ & $2.15 \mathrm{~m}$ & $3.08 \mathrm{dd}(14.1,6.1)$ & $2.05 \mathrm{~m}$ \\
\hline & $3.02 \mathrm{~m}$ & $1.88 \mathrm{~m}$ & $2.76 \mathrm{~m}$ & $2.71 \mathrm{~m}$ \\
\hline 23 & $2.39 \mathrm{~m}, 2.05 \mathrm{~m}$ & $2.19 \mathrm{~m}, 2.02 \mathrm{~m}$ & $6.21 \mathrm{~m}$ & $2.62 \mathrm{~m}, 2.29 \mathrm{~m}$ \\
\hline 24 & & $4.42 \mathrm{t}(6.0)$ & $6.08 \mathrm{~d}(15.7)$ & $5.35 \mathrm{tt}(7.1,1.2)$ \\
\hline $\mathrm{OH}-24$ & & $6.41 \mathrm{~s}$ & & \\
\hline OOH-25 & & & $14.37 \mathrm{~s}$ & \\
\hline 26 & $6.06 \mathrm{~s}, 5.66 \mathrm{~s}$ & $5.25 \mathrm{~m}, 4.97 \mathrm{~m}$ & $1.59 \mathrm{~s}$ & $1.68 \mathrm{~s}$ \\
\hline 27 & $1.89 \mathrm{~s}$ & $1.92 \mathrm{~s}$ & $1.60 \mathrm{~s}$ & $1.64 \mathrm{~s}$ \\
\hline 28 & $2.02 \mathrm{~s}$ & $1.67 \mathrm{~s}$ & $1.68 \mathrm{~s}$ & $1.79 \mathrm{~s}$ \\
\hline 29 & $1.47 \mathrm{~s}$ & $1.70 \mathrm{~s}$ & $1.73 \mathrm{~s}$ & $1.89 \mathrm{~s}$ \\
\hline 30 & $0.97 \mathrm{~s}$ & $0.91 \mathrm{~s}$ & $1.09 \mathrm{~s}$ & $0.88 \mathrm{~s}$ \\
\hline $1^{\prime}$ & & & $5.26 \mathrm{~d}(7.7)$ & $5.04 \mathrm{~d}(7.8)$ \\
\hline $2^{\prime}$ & & & $4.04 \mathrm{~m}$ & $4.08 \mathrm{~m}$ \\
\hline $3^{\prime}$ & & & $4.27 \mathrm{~m}$ & $4.25 \mathrm{~m}$ \\
\hline $4^{\prime}$ & & & $4.17 \mathrm{~m}$ & $4.23 \mathrm{~m}$ \\
\hline $5^{\prime}$ & & & $4.03 \mathrm{~m}$ & $3.96 \mathrm{~m}$ \\
\hline $6^{\prime}$ & & & $4.55 \mathrm{~d}(11.4)$ & $4.57 \mathrm{~d}(11.3)$ \\
\hline & & & $4.35 \mathrm{~m}$ & $4.38 \mathrm{~m}$ \\
\hline
\end{tabular}

was further verified by the HMBC correlations from $\mathrm{H}_{2}-2$ $\left(\delta_{\mathrm{H}} 2.82,2.32\right), \mathrm{H}-28\left(\delta_{\mathrm{H}} 1.68\right)$ and $\mathrm{H}-29\left(\delta_{\mathrm{H}} 1.73\right)$ to $\mathrm{C}-3$ $\left(\delta_{\mathrm{C}} 219.1\right)$. Moreover, on the basic of the correlations of $\delta_{\mathrm{H}}$ $14.37(-\mathrm{OOH})$ with $\mathrm{C}-25\left(\delta_{\mathrm{C}} 81.8\right), \mathrm{H}-1^{\prime}\left(\delta_{\mathrm{H}} 5.26\right)$ with C-20 $\left(\delta_{\mathrm{C}} 83.5\right)$ in HMBC spectrum and H-1'with $\mathrm{H}-21\left(\delta_{\mathrm{H}} 1.62\right.$, $\mathrm{s}) / \mathrm{H}_{2}-22\left(\delta_{\mathrm{H}} 3.08 \mathrm{dd}, J=14.1,6.1 \mathrm{~Hz} ; \delta_{\mathrm{H}} 2.76 \mathrm{~m}\right) / \mathrm{H}-23\left(\delta_{\mathrm{H}}\right.$ $6.21, \mathrm{~m})$ in ROESY spectrum, the positions of peroxy and glucosyl groups were confirmed to be linked with C-25 and C-20, respectively. Therefore, compound $\mathbf{3}$ was assigned as 3-oxo-20(S)-ginsenoside- $\mathrm{Rh}_{6}$.

Compound 4 was an amorphous white powder and had a molecular formula $\mathrm{C}_{36} \mathrm{H}_{60} \mathrm{O}_{9}$, as deduced from HRESIMS experiment $\left(m / z, 659.4126[\mathrm{M}+\mathrm{Na}]^{+}\right)$. An $\beta$-Dglucopyranosyl unit $\left(\delta_{\mathrm{C}} 105.8 \mathrm{~d}, 80.1 \mathrm{~d}, 78.6 \mathrm{~d}, 75.9 \mathrm{~d}, 72.4\right.$ 

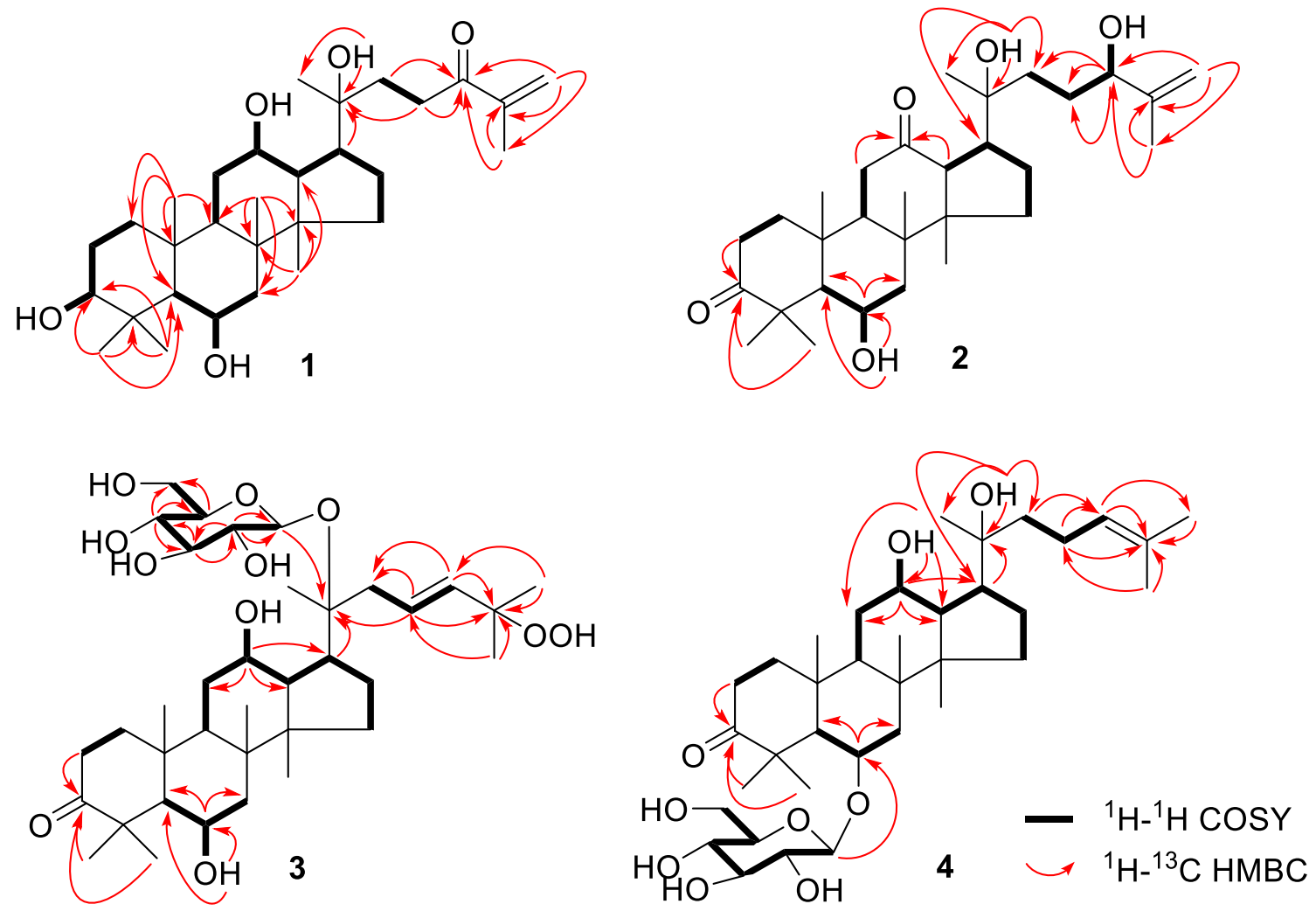

Fig. 2 Key ${ }^{1} \mathrm{H}_{-}{ }^{1} \mathrm{H}$ COSY and ${ }^{1} \mathrm{H}^{-13} \mathrm{C}$ HMBC correlations of compounds $\mathbf{1}-\mathbf{4}$

$\mathrm{d}, 63.6 \mathrm{t})$ could be recognized by ${ }^{13} \mathrm{C}$ NMR data and the anomeric proton at $\delta_{\mathrm{H}} 5.04(\mathrm{~d}, J=7.8 \mathrm{~Hz})$, and confirmed by $\mathrm{GC}$ analysis after acidic hydrolysis. Furthermore, the HMBC correlations from $\mathrm{H}-5 / \mathrm{H}-7 / \mathrm{H}-1$ ' to C-6 $\left(\delta_{\mathrm{C}} 79.8\right)$ indicated the glucosyl group was substituted at $\mathrm{C}-6$. The ${ }^{1} \mathrm{H}$ and ${ }^{13} \mathrm{C}$ NMR data of $\mathbf{4}$ were in good agreement with those of $20(S)$ ginsenoside- $\mathrm{Rh}_{1}[16]$, except for signals of ring $\mathrm{A}$, which showed a lower field quaternary carbon at $\delta_{\mathrm{C}} 219.0$. Similar to those of $\mathbf{2}$ and $\mathbf{3}, \mathrm{H}_{2}-2\left(\delta_{\mathrm{H}} 2.83,2.31\right), \mathrm{CH}_{3}-28\left(\delta_{\mathrm{H}} 1.79, \mathrm{~s}\right)$ and $\mathrm{CH}_{3}-29\left(\delta_{\mathrm{H}} 1.89, \mathrm{~s}\right)$ displayed HMBC correlations with $\delta_{\mathrm{C}} 219.0$, indicating that 4 was an oxidized ginsenoside- $\mathrm{Rh}_{1}$ at C-3. The absolute configuration of C-20 $\left(\delta_{\mathrm{C}} 73.5\right)$ was identified as $20 \mathrm{~S}$ when compared its surrounding carbon signals [C-17 $\left(\delta_{\mathrm{C}} 55.1\right), \mathrm{C}-21\left(\delta_{\mathrm{C}} 27.5\right)$ and C-22 $\left.\left(\delta_{\mathrm{C}} 36.3\right)\right]$ with that in 3-oxo-20 $(R)$-ginsenoside- $\mathrm{Rh}_{1}\left[\mathrm{C}-17\left(\delta_{\mathrm{C}} 50.9\right)\right.$, C-21 $\left(\delta_{\mathrm{C}} 23.2\right)$, and C-22 $\left.\left(\delta_{\mathrm{C}} 43.6\right)\right]$ [17]. Accordingly, compound 4 was identified as 3-oxo-20(S)-ginsenoside- $\mathrm{Rh}_{1}$.

Four known compounds were identified as $6 \alpha, 20(S), 24(S)$-trihydroxydammar-3,12-dione-25-ene (5) [11], ginsenoside- $\mathrm{F}_{1}(6)$ [18], 12-oxo-20(S)-protopanaxatriol (7) [19], 6 $\alpha, 12 \beta$-dihydroxydammar-3-one-20(S)-O$\beta$-D-glucopyranoside (8) [20], respectively, by comparison of their spectroscopic data with literature reported values. Related substrate specificity test probed that the glucoside bond of ginsenoside $\mathrm{Rg}_{1}$ can be selectively hydrolyzed by
$\beta$-D-glucosidase and thus produced rare ginsenoside $\mathrm{F}_{1}$ [21]. Accordingly, $\beta$-D-glucosidase is widespread in fungi [22] and bacteria [23], and the oxidative stress response in this herb after infected by the root rot decease might play the main role for the oxidation of hydroxyl group at C-3, C-12, or the side chain. As all the eight compounds are PPT-type triterpenes, we speculated that they might be transformed from ginsenoside $\mathrm{Rg}_{1}$, the most abundant PPT-type saponin in the root of $P$. notoginseng, and the possible transformation pathway of these eight compounds were deduced as Fig. 3.

Compound $\mathbf{1}$ is a triterpene aglycone with a terminal $\alpha, \beta-$ unsaturated ketene on the side chain, whose diglycoside and triglycoside in flower buds of $P$. notoginseng and tetraglycoside in Xueshuantong Injection were reported previously by LC-MS(Q-TOF) analysis [24, 25]. In the present study, compound $\mathbf{1}$ was isolated and identified with other three new compounds (2-4) and four known ones from the rot roots of $P$. notoginseng for the first time. Compounds $\mathbf{2}$ and $\mathbf{5}$ were a pair of diastereoisomers and separated simultaneously by semi-preparative HPLC.

Since the glycosides in Panax species were reported to have strong anti-inflammatory and anti-tumor activities [24-30], all the isolates were evaluated for their inhibitory effects against NO production on Murine macrophage cell line and cytotoxicities against five human cancer cells 


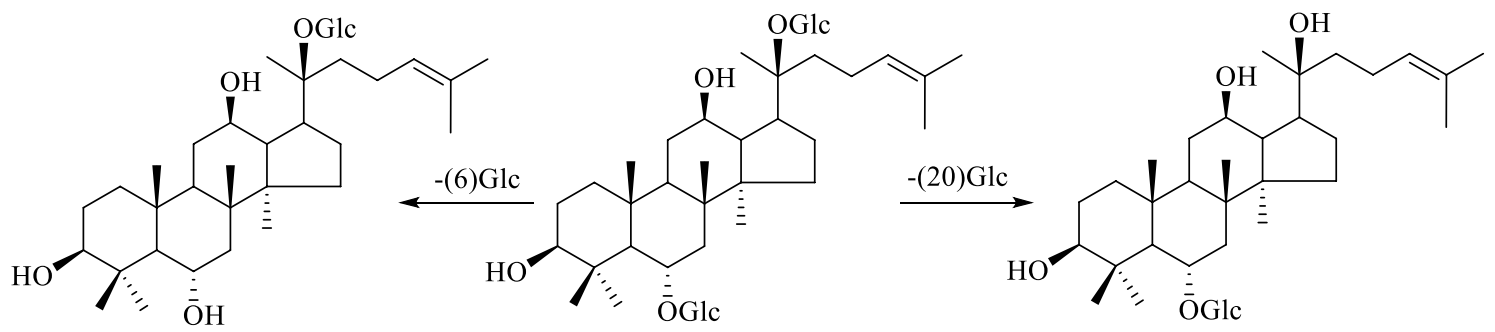

Ginsenoside $F_{1}(7)$

Ginsenoside $\operatorname{Rg}_{1}$

Ginsenoside $\mathrm{Rh}_{1}$

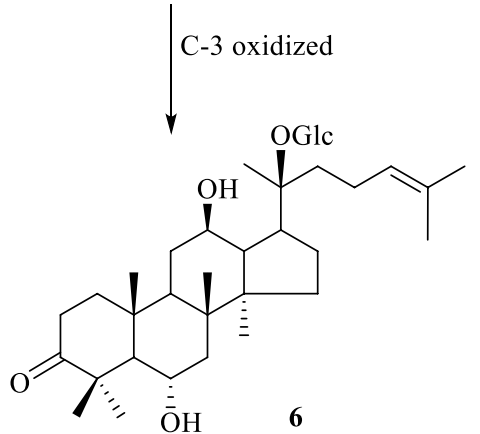

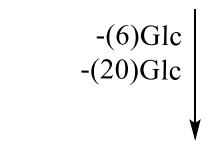
C-3 oxidized

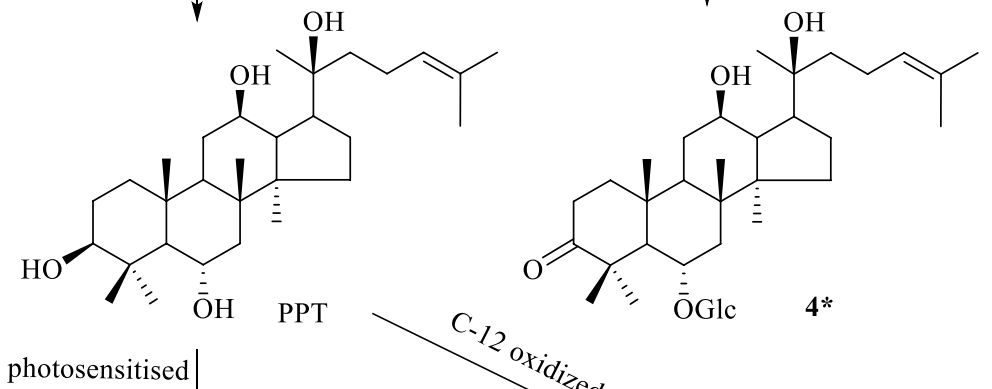
photosensitised oxidation

photosensitised oxidation

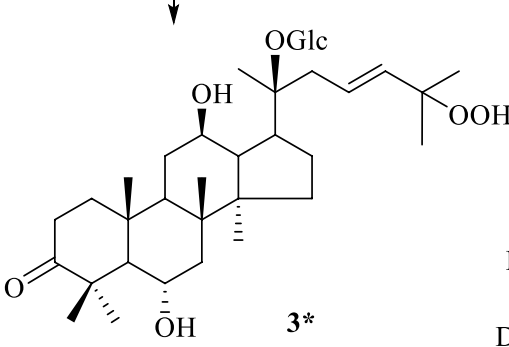

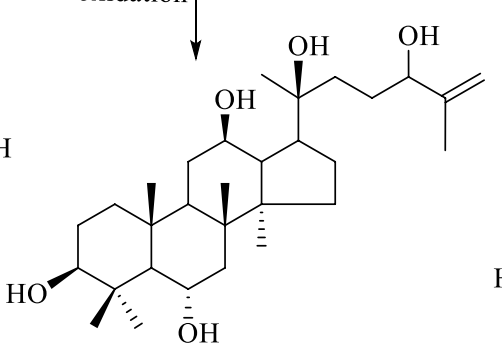

Dammar-25-ene-3,6,12,20,24-pentanol<smiles>CC(C)=CCC[C@](C)(O)C1CC[C@]2(C)C1C(=O)CC1[C@@]3(C)CC[C@@H](O)C(C)(C)C3[C@@H](O)C[C@]12C</smiles><smiles>C=C(C)C(=O)CC[C@](C)(O)C1CC[C@]2(C)C1C(O)CC1[C@]2(C)C[C@H](O)C2C(C)(C)[C@@H](O)CC[C@@]21C</smiles>

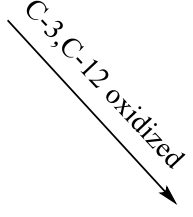

-24 oxidized<smiles>CC[C@@]1(C)C[C@H](O)C2C(C)(C)C(=O)CC[C@@]2(C)C1C</smiles>

Fig. 3 The possible transformation pathway of 1-8 from ginsenoside $\operatorname{Rg}_{1}$

(myeloid leukemia HL-60, lung cancer A-549 cells, hepatocellular carcinoma SMMC7721, breast cancer MCF-7, and colon cancer SW480). Only compound 1 displayed significant inhibition of NO production with $\mathrm{IC}_{50}$ value of $4.12 \pm 0.2 \mu \mathrm{M}$ (L-NMMA: $\left.\mathrm{IC}_{50}=34.32 \pm 1.20 \mu \mathrm{M}\right)$ and obvious cytoxicities against all the five human cancer cell lines, comparable to the positive control, DDP (Table 3). At primary concentration of $50 \mu \mathrm{M}$ for NO inhibition and $40 \mu \mathrm{M}$ for cytotoxicity, the other compounds 2-8 displayed no obvious anti-inflammatory and cytotoxic activities.

\section{Experimental}

\subsection{General Experimental Procedures}

Optical rotations were measured with a P-1020 polarimeter (JASCO, Tokyo, Japan). IR spectra were measured on Bio-Rad FTS-135 series spectrometer or NICOLLET iS10 with OMNIC 9.8.372 software. UV spectra were recorded on a Shimadzu UV2401A ultra-violet-visible spectrophotometer. HRESIMS spectra were run on an API QSTAR 
Table 3 Cytotoxicities of compound $\mathbf{1}$ against five human cancer cell lines

\begin{tabular}{llrl}
\hline Cancer cells & \multicolumn{2}{l}{$\mathrm{IC}_{50} \pm \mathrm{SD}(\mu \mathrm{M})$} & \\
\cline { 2 - 4 } & $\mathbf{1}$ & \multicolumn{1}{l}{$\mathrm{DDP}$} & Taxol \\
\hline Myeloid leukemia HL-60 & $19.12 \pm 0.21$ & $2.87 \pm 0.08$ & $<0.008$ \\
Lung cancer A-549 & $16.30 \pm 0.21$ & $20.62 \pm 2.70$ & $<0.008$ \\
Hepatocellular carcinoma & $16.69 \pm 0.33$ & $17.40 \pm 0.51$ & $<0.008$ \\
$\quad$ SMMC7721 & & & \\
Breast cancer MCF-7 & $16.78 \pm 0.32$ & $14.96 \pm 0.45$ & $<0.008$ \\
Colon cancer SW480 & $13.58 \pm 0.71$ & $14.34 \pm 1.15$ & $<0.008$ \\
\hline
\end{tabular}

Data expressed as mean $\pm \mathrm{SD}(\mathrm{n}=3)$

Pular-1 spectrometer. NMR spectra were measured in pyridine- $d_{5}$ and recorded on a Bruker DRX-600 spectrometer, using TMS as an internal standard. Chemical shifts were reported in units of $\delta(\mathrm{ppm})$ and coupling constants $(J)$ were expressed in Hz. Column chromatography (CC) were carried out over macro-porous resin D101 (Cangzhou Baoeng Co. Ltd., China), silica gel (200-300 mesh, Qingdao Haiyang Chemical Co. Ltd., China), RP-C18

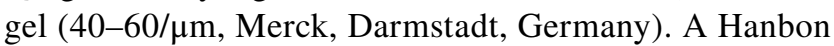
series (Hanbon Sci \& Tech) were used for semi-preparative HPLC with a Capcell Pak MGII C18 column $(5 \mu \mathrm{m}$, $250 \mathrm{~mm} \times 10 \mathrm{~mm})$.

\subsection{Plant Material}

The rot roots of $P$. notoginseng (Burk.) F. H. Chen were collected in Wenshan County, Yunnan Province, People's Republic of China, in February 2017, and identified by Prof. C. R. Yang from Kunming Institute of Botany (KIB), Chinese Academy of Sciences (CAS). A voucher specimen (KIB-Z-2017001) was deposited in the State Key Laboratory of Phytochemistry and Plant Resource in West China of $\mathrm{KIB}, \mathrm{CAS}$.

\subsection{Extraction and Isolation}

The fresh rot roots of $P$. notoginseng $(70 \mathrm{~kg})$ were cut from the healthy part, air-dried under room temperature, and then extracted with $\mathrm{CH}_{3} \mathrm{OH}$ three times. After removal of the organic solvent, the methanol extract $(4.0 \mathrm{~kg})$ was subjected to macro-porous resin D101 CC $(250 \times 30 \mathrm{~cm})$ eluting with $\mathrm{H}_{2} \mathrm{O}$ to remove most of the saccharides and then washing with $\mathrm{MeOH}$ to give a crude saponins fraction $(2.7 \mathrm{~kg})$, which was further fractionated on a silica gel $\mathrm{CC}(250 \times 30 \mathrm{~cm})$, eluting with $\mathrm{CHCl}_{3}-\mathrm{CH}_{3} \mathrm{OH}(7: 3)$, to afford three fractions (Fr. A-C). TLC and HPLC analysis showed Fr. A (220.8 g) containing mainly notoginsenoside $\mathrm{R}_{1}$ and ginsenosides $\mathrm{Rg}_{1}$, $\mathrm{Re}, \mathrm{Rd}$ and $\mathrm{Rb}_{1}$.
Fr. C (220.8 g) was applied to RP-18 CC, eluting with $\mathrm{CH}_{3} \mathrm{OH}-\mathrm{H}_{2} \mathrm{O}$ (1:9 to 9:1), to yield six sub-fractions (Fr. C1-C6). Fr. C2 (1.2 g) was column chromatographed over silica gel CC, eluting with $\mathrm{CHCl}_{3}-\mathrm{CH}_{3} \mathrm{OH}(10: 1)$ to give eight sub-fractions (Frs. C1.1-C1.8). Fr. C1.4 (37 mg) and Fr. C1.5 (21 mg) were separately purified with semi-preparative $\mathrm{HPLC}\left(\mathrm{CH}_{3} \mathrm{CN}-\mathrm{H}_{2} \mathrm{O}, 35: 65\right)$ to yield 7 (2.9 $\left.\mathrm{mg}\right)$ and 8 (10.0 mg), 4 (6.2 mg) and 6 (20 mg). Fr. C1.6 (21 mg) was purified with semi-preparative $\mathrm{HPLC}\left(\mathrm{CH}_{3} \mathrm{CN}-\mathrm{H}_{2} \mathrm{O}, 31: 69\right)$ to yield 3 (4.2 mg). Fr. C3 (4 g) was subjected to a silica gel CC eluting with $\mathrm{CHCl}_{3}-\mathrm{CH}_{3} \mathrm{OH}$ (200:1 to 95:5), followed with semi-preparative $\mathrm{HPLC}\left(\mathrm{CH}_{3} \mathrm{CN}-\mathrm{H}_{2} \mathrm{O}, 35: 65\right)$ to yield 1 (4.0 mg). Fr. C5 (1.1 g) was subjected to a silica gel CC eluting with $\mathrm{CHCl}_{3}-\mathrm{CH}_{3} \mathrm{OH}$ (200:1 to $\left.10: 1\right)$, followed with semi-preparative $\mathrm{HPLC}\left(\mathrm{CH}_{3} \mathrm{CN}-\mathrm{H}_{2} \mathrm{O}, 44: 56\right)$ to yield 5 $(2.8 \mathrm{mg})$ and $2(2.5 \mathrm{mg})$.

\subsection{1 $3 \beta, 6 a, 12 \beta, 20(S)$-Tetrahydroxydammar-24-one-25- ene (1)}

White amorphous powder; $[\alpha]_{\mathrm{D}}^{25}-24.83(c 0.06, \mathrm{MeOH})$; IR $(\mathrm{KBr}) \nu_{\max }: 3391,2954,2924,2853,1738,1674,1463$, 1414, 1031; UV (MeOH) $\lambda_{\max }(\log \varepsilon): 254(0.10), 196(0.35)$ nm; ${ }^{13} \mathrm{C}$ and ${ }^{1} \mathrm{H}$ NMR data: see Tables 1 and 2; HRESIMS (pos.): $m / z 513.3551[\mathrm{M}+\mathrm{Na}]^{+}$, (calcd. for $\mathrm{C}_{30} \mathrm{H}_{50} \mathrm{O}_{5} \mathrm{Na}$, 513.3550).

\subsection{2 $6 a, 20(S), 24(R)$-Trihydroxydammar-3,12-dione-25-ene} (2)

White amorphous powder; $[\alpha]_{\mathrm{D}}^{25}+94.95(c 0.08, \mathrm{MeOH})$; IR (ATR) $\nu_{\max }: 3478,3452,3405,2956,2916,2880,1690$, 1111; UV $(\mathrm{MeOH}) \lambda_{\max }(\log \varepsilon): 195(0.35) \mathrm{nm} ;{ }^{13} \mathrm{C}$ and ${ }^{1} \mathrm{H}$ NMR data: see Tables 1 and 2; HRESIMS (pos.): $\mathrm{m} / \mathrm{z}$ 511.3399 [M+Na] ${ }^{+}$, (calcd. for $\mathrm{C}_{30} \mathrm{H}_{48} \mathrm{O}_{5} \mathrm{Na}, 511.3399$ ).

\subsubsection{3-0xo-20(S)-ginsenoside- $\mathrm{Rh}_{6}(3)$}

White amorphous powder; $[\alpha]_{\mathrm{D}}^{25}+70.67(c 0.12, \mathrm{MeOH})$; IR (ATR) $\nu_{\max }: 3356,2956,2934,2880,1692,1425,1380$, 1076, 1035; UV (MeOH) $\lambda_{\max }(\log \varepsilon): 195(0.37) \mathrm{nm} ;{ }^{13} \mathrm{C}$ and ${ }^{1} \mathrm{H}$ NMR data: see Tables 1 and 2; HRESIMS (pos.): $\mathrm{m} / \mathrm{z}$ 691.4024 [M+Na $]^{+}$, (calcd. for $\mathrm{C}_{36} \mathrm{H}_{60} \mathrm{O}_{11} \mathrm{Na}, 691.4033$ ).

\subsubsection{3-0xo-20(S)-ginsenoside $\mathrm{Rh}_{1}(4)$}

White amorphous powder; $[\alpha]_{\mathrm{D}}^{25}+61.42(c 0.13, \mathrm{MeOH})$; IR (KBr) $\nu_{\text {max }}: 3422,2964,2931,2877,1691,1637,1458$, 1383, 1077, 1022; UV (MeOH) $\lambda_{\text {max }}(\log \varepsilon): 196(0.52)$, 254 (0.07) nm; ${ }^{13} \mathrm{C}$ and ${ }^{1} \mathrm{H}$ NMR data: see Tables 1 and 2; HRESIMS (pos.): $m / z$ 659.4126 [M+Na $]^{+}$, (calcd. for $\left.\mathrm{C}_{36} \mathrm{H}_{60} \mathrm{O}_{9} \mathrm{Na}, 659.4135\right)$. 


\subsection{Acid Hydrolysis of Compounds 3 and 4}

Compounds 3 and 4 (each $2.0 \mathrm{mg}$ ) were hydrolyzed in $2 \mathrm{M}$ $\mathrm{HCl}(3 \mathrm{~mL})$ at $65^{\circ} \mathrm{C}$ for $4 \mathrm{~h}$, respectively. The reaction mixture was extracted with $\mathrm{CH}_{2} \mathrm{Cl}_{2}$, three times $(3 \times 3 \mathrm{~mL})$. The aqueous layer was neutralized with $2 \mathrm{M} \mathrm{NaOH}$ and dried to produce a monosaccharide mixture. Next, L-cysteine methyl ester hydrochloride $(1.0 \mathrm{mg})$ was added to a no aqueous pyridine solution of the sugar mixture $(1.0 \mathrm{~mL})$ and kept at $60{ }^{\circ} \mathrm{C}$ for $1 \mathrm{~h}$. After this, trimethylsilylimidazole $(1.0 \mathrm{~mL})$ was added to the reaction mixture and kept at $60{ }^{\circ} \mathrm{C}$ for $30 \mathrm{~min}$, followed the extraction with $n$-hexane $(1 \times 2 \mathrm{~mL})$. The $n$-hexane layer was subjected to GC analysis, run on a Agilent Technologies HP5890 gas chromatograph, equipped with a HP-5 quartz capillary column (30 $\mathrm{mm} \times 0.32 \mathrm{~mm} \times 0.25 \mathrm{~mm}$ ) and $\mathrm{a}_{2}$ flame ionization detector with the following conditions: column temperature, 180-280 ${ }^{\circ} \mathrm{C}$; programmed increase, $3{ }^{\circ} \mathrm{C} / \mathrm{min}$; carrier gas, $\mathrm{N}_{2}(1.5 \mathrm{~mL} / \mathrm{min})$; injector and detector temperature, $250{ }^{\circ} \mathrm{C}$; injection volume, $2.0 \mu \mathrm{L}$; and split ratio $1 / 50$. The configuration of the sugar moiety was determined by comparing the retention time with the derivatives of the authentic samples. The retention times of D-/L-glucose were 20.418/20.825 min, and the configuration of the respective sugar moiety from compounds $\mathbf{3}$ and $\mathbf{4}$ was determined as D-glucose.

\subsection{The Nitric Oxide Production in RAW264.7 Macrophages}

As reported previously [31, 32], murine macrophage cell line RAW264.7 obtained from Cell Bank of Chinese Academy of Sciences (Beijing, People's Republic of China), were seeded in 96 -well cell culture plates $\left(1.5 \times 10^{5}\right.$ cells/well $)$ and treated with serial dilutions of the compounds with a maximum concentration of $50 \mu \mathrm{M}$ in triplicate, followed by stimulation with $1 \mu \mathrm{g} / \mathrm{mL}$ LPS (Sigma, St. Louis, MO, USA) for $18 \mathrm{~h}$. Nitric oxide production in the supernatant was assessed by Griess reagents (Reagent A \& Reagent $\mathrm{B}$, respectively, Sigma). The absorbance at $570 \mathrm{~nm}$ was measured with a microplate reader (Thermo, Waltham, MA, USA). NG-Methyl-L-arginine acetate salt (L-NMMA, Sigma), a well-known nitric oxide synthase (NOS) inhibitor, was used as a positive control. All the compounds were prepared as stock solutions in DMSO. The viability of RAW264.7 cells was evaluated by the MTS assay simultaneously to exclude the interference of the cytotoxicity of the test compounds. Concentration of a compound inhibiting $50 \%$ of cell growth $\left(\mathrm{IC}_{50}\right)$ was calculated by the Reed and Muench method.

\subsection{Cytotoxic Assay}

Five human cancer cell lines, myeloid leukemia HL-60, lung cancer A-549 cells, hepatocellular carcinoma SMMC7721, breast cancer MCF-7, and colon cancer SW480, were used in the cytotoxic assay. All the cells were cultured in RPMI-1640 or DMEM medium (Hyclone, USA), supplemented with $10 \%$ fetal bovine serum (Hyclone, USA). The cytotoxicity assay was performed according to the MTS [3-(4,5-dimethylthiazol-2-yl)-5(3-carboxymethoxy-phenyl)2-(4-sulfopheny)-2H-tetrazolium] method in 96-well microplates [33]. Briefly, adherent cells $(100 \mu \mathrm{L})$ was seeded into each well of 96-well cell culture plates and allowed to adhere for $24 \mathrm{~h}$ before drug addition, while suspended cells were seeded just before drug addition, each tumor cell line was exposed to the test compound dissolved in DMSO in triplicates for $48 \mathrm{~h}$ at $37{ }^{\circ} \mathrm{C}$, with DDP and Taxol (Sigma, USA) as positive controls. After the incubation, $20 \mu \mathrm{L} \mathrm{MTS} \mathrm{and}$ $100 \mu \mathrm{L}$ medium were added to each well after removal of $100 \mu \mathrm{L}$ medium, and the incubation continued for $4 \mathrm{~h}$ at $37{ }^{\circ} \mathrm{C}$. The optical density was measured at $492 \mathrm{~nm}$ using a Multiskan FC plate reader (Thermo Scientific, USA). Concentration of a compound inhibiting $50 \%$ of cell growth $\left(\mathrm{IC}_{50}\right)$ was calculated by the Reed and Muench method.

\section{Conclusion}

In summary, eight PPT-type triterpenes $(\mathbf{1}-\mathbf{2}, \mathbf{5}, \mathbf{8})$ and saponins $(\mathbf{3}-\mathbf{4}, \mathbf{6}-\mathbf{7})$ were isolated from the rot roots of $P$. notoginseng for the first time. Among them, 1-4 are new compounds. Their structures were determined on the basis of the extensive spectroscopic analyses and acidic hydrolysis. Compound 1 with a novel terminal ketene at C-24 to C-26 showed significant cytotoxic and anti-inflammatory activities.

Acknowledgements The authors are grateful to the members of the analytical and bioactivity screening groups at the State Key Laboratory of Phytochemistry and Plant Resources in West China, KIB, CAS, for measuring the spectroscopic data and cytotoxic assay. This work was supported by the Major Science and Technique Programs in Yunnan Province (2016ZF001-001), the Science and Technology Planning Project of Yunnan Province (2013FC008) and Yung-Chi Cheng academician workstation of Yunnan provincial academy of science and technology (2015IC017).

\section{Compliance with Ethical Standards}

Conflict of interest The authors declare that there are no conflicts of interest. 
Open Access This article is distributed under the terms of the Creative Commons Attribution 4.0 International License (http://creativeco mmons.org/licenses/by/4.0/), which permits unrestricted use, distribution, and reproduction in any medium, provided you give appropriate credit to the original author(s) and the source, provide a link to the Creative Commons license, and indicate if changes were made.

\section{References}

1. Y.J. Qiao, J.H. Shang, D. Wang, H.T. Zhu, C.R. Yang, Y.J. Zhang, Nat. Prod. Bioprospect. 8, 245-263 (2018)

2. P.G. Xia, S.C. Zhang, Z.S. Liang, Z.H. Qi, Chin. Tradit. Herb. Drugs. 45, 2564-2570 (2014)

3. N. Jiang, L.Y. Qin, Y.F. Ye, J. South. Agric. 42, 1070-1074 (2011)

4. X.T. Sun, L. Li, G.Q. Long, G.H. Zhang, Z.G. Meng, S.C. Yang, J.W. Chen, Chin. J. Ecol. 34, 885-893 (2015)

5. Z.S. Mao, Y.J. Long, S.S. Zhu, Z.J. Chen, F.G. Wei, Y.X. Zhu, X.H. He, Chin. Med. Mater. 36, 2051-2054 (2013)

6. T. Wang, R. Guo, G. Zhou, X. Zhou, Z. Kou, F. Sui, C. Li, L. Tang, Z. Wang, J. Ethnopharmacol. 188, 234-258 (2016)

7. R.Q. Tai, W.Z. Tan, E. Yang, Y. Feng, H.Z. Li, J. Kunming. Univ. Sci. Technol. (Nat. Sci) 40, 85-88 (2015)

8. S.R. Ko, K.J. Choi, K. Suzuki, Y. Suzuki, Chem. Pharm. Bull. 51, 404-408 (2003)

9. J. Asakawa, R. Kasai, K. Yamasaki, O. Tanaka, Tetrahedron 33, 1935-1939 (1997)

10. S. Fujita, R. Kasai, K. Ohtani, K. Yamasaki, M.H. Chiu, R.L. Nie, O. Tanaka, Phytochemistry 39, 591-602 (1995)

11. J.L. Yang, T.K.Q. Ha, B. Dhodary, K.H. Kim, J. Park, C.H. Lee, Y.C. Kim, W.K. Oh, J. Nat. Prod. 77, 1615-1623 (2014)

12. L.P. Christensen, Advances in Food and Nutrition Research (Elsevier, Cambridge, 2008), pp. 1-99

13. E. Bedir, N.J. Toyang, I.A. Khan, L.A. Walker, A.M. Clark, J. Nat. Prod. 64, 95-97 (2001)

14. L.W. Qi, C.Z. Wang, C.S. Yuan, Nat. Prod. Rep. 28, 467-495 (2011)

15. D.Y. Lee, B.J. Cha, Y.S. Lee, G.S. Kim, H.J. Noh, S.Y. Kim, H.C. Kang, H.K. Jin, N.I. Baek, Int. J. Mol. Sci. 16, 1677 (2015)
16. R.T. Teng, H.Z. Li, J.T. Chen, D.Z. Wang, Y.E. He, C.R. Yang, Magn. Reson. Chem. 40, 483-488 (2002)

17. L.B. Vinh, Y. Lee, Y.K. Han, J.S. Kan, J.U. Park, Y.R. Kim, S.Y. Yang, Y.H. Kim, Bioorg. Med. Chem. Lett. 27, 5149-5153 (2017)

18. Y.W. Zhang, Q.D. De, Y.J. Chen, X.S. Yao, Chin. Tradit. Herb. Drugs. 49, 442-446 (2001)

19. J. Zhang, H. Guo, Y. Tian, P. Liu, N. Li, J. Zhou, D. Guo, Phytochemistry 68, 2523-2530 (2007)

20. X. Liu, L.R. Qiao, D. Xie, J.G. Dai, J. Asian Nat. Prod. Res. 13, 652-658 (2011)

21. Q. Zhang, W.Q. Zhao, F. Meng, Y.X. Zhang, Chin. J. Antibiot. 37, 49-75 (2012)

22. M. Miyazawa, H. Ando, Y. Okuno, J. Mol. Catal B 27, 91-95 (2004)

23. Y.H. Pyo, T.C. Lee, Y.C. Lee, Food Res. Int. 38, 551-559 (2005)

24. W.Z. Yang, T. Bo, S. Ji, X. Qiao, D.A. Guo, M. Ye, Food Chem. 139, 762-769 (2013)

25. W.Z. Yang, J.X. Zhang, C.J. Yao, S. Qiu, M. Chen, H.Q. Pan, X.J. Shi, W.Y. Wu, D. Guo, J. Pharm. Biomed. Anal. 128, 322-332 (2016)

26. A. Rhule, S. Navarro, J.R. Smith, D.M. Shepherd, J. Ethnopharmacol. 106, 121-128 (2006)

27. S. Ahn, M.H. Siddiqi, H.Y. Noh, Y.J. Kim, Y.J. Kim, C.G. Jin, D.C. Yang, Sci. Bull. 60, 773-784 (2015)

28. N.W. He, Y. Zhao, L. Guo, J. Shang, X.B. Yang, J. Med. Food 15, 350-359 (2012)

29. D.F. Toh, D.N. Patel, E.C.Y. Chan, A. Teo, S.Y. Neo, H.L. Koh, Chin. Med. 6, 1-9 (2011)

30. P. Wang, J. Cui, X. Du, Q. Yang, C. Jia, M. Xiong, X. Yu, L. Li, W. Wang, Y. Chen, T. Zhang, J. Ethnopharmacol. 154, 663-671 (2014)

31. V.M. Dirsch, H. Stuppner, A.M. Vollmar, Planta Med. 64, 423$426(1998)$

32. D.W. Reif, S.A. Mccreedy, Arch. Biochem. Biophys. 320, 170176 (1995)

33. K. Berg, L. Zhai, M. Chen, A. Kharazmi, T.C. Owen, Parasitol. Res. 80, 235-239 (1994) 